\title{
Revisiting the boundary between the Lower and Upper Vindhyan, Son valley, India
}

\author{
Sabyasachi Mandal ${ }^{1}$, Adrita Choudhuri ${ }^{2}$, Indrani Mondal $^{1}$, Subir Sarkar $^{1, *}$, \\ Partha Pratim Chakraborty ${ }^{3}$ and Santanu Banerjee ${ }^{4}$ \\ ${ }^{1}$ Department of Geological Sciences, Jadavpur University, Kolkata 700 032, India. \\ ${ }^{2}$ Department of Earth Sciences, Indian Institute of Science Education and Research, Kolkata, Mohanpur, \\ West Bengal 741246 , India. \\ ${ }^{3}$ Department of Geology, University of Delhi, New Delhi 110 00\%, India. \\ ${ }^{4}$ Department of Earth Sciences, Indian Institute of Technology Bombay, Mumbai 400 076, India. \\ *Corresponding author.e-mail: jugeoss@gmail.com
}

MS received 3 February 2019; revised 12 June 2019; accepted 13 June 2019

The placement of the boundary between the Lower and the Upper Vindhyan in the Son valley, an unconformity, has long been at the centre of a raging debate. At the Bundelkhand sector, it is placed between the Rohtas Limestone and the Sasaram Sandstone (Lower Quartzite). On the other hand, in the Son valley sector, it is placed between the Bhagwar Shale and the Kaimur Formation. The recent study reveals the existence of ca. $12 \mathrm{~m}$ thick sandstone between the Bhagwar Shale and Rohtas Limestone, traced over $150 \mathrm{~km}$ in the Son valley sector. Based on in-depth facies constituents and facies tracts, this sandstone is an exact equivalent of the Sasaram Sandstone in the Bundelkhand sector. Its base is strongly erosional and limestone and chert clasts derived from the underlying Rohtas Limestone are abundantly present at the basal part of the sandstone and the unconformity between the Upper and Lower Vindhyan are likely to be present in between.

Keywords. Lower Vindhyan; Upper Vindhyan; unconformable boundary; transgressive lag; persistent sandstone horizon; subtidal deposit.

\section{Introduction}

The Palaeo to the Neoproterozoic Vindhyan Supergroup, the largest 'Purana' basin in India and the world's second-largest Proterozoic basin, is one of the most well studied and focused Proterozoic successions in India (figure 1a; Auden 1933; Banerjee 1974; Sastry and Moitry 1984; Bhattacharyya 1996; Rai et al. 1997; Seilacher et al. 1998; Bose et al. 2001, 2015; Rasmussen et al. 2002; Ray et al. 2002; Sarkar et al. 2002a, 2004, 2006, 2014; Banerjee et al. 2006; Malone et al. 2008; Bengtson et al. 2009, 2017; Kumar and Sharma 2011; Chakraborty Published online: 10 August 2019 et al. 2012; Gopalan et al. 2013; Tripathy and Singh 2015; Bickford et al. 2017; Gilleaudeau et al. 2018; Mishra et al. 2018; Sallstedt et al. 2018). The Vindhyan basin, exposed in the eastern part of central India can be divided into the Bundelkhand sector and the Son valley sector (figure 1a, Chakraborty 2006; Chakraborty et al. 2010). The basin-wide unconformity divides the Vindhyan succession into two parts, the Lower Vindhyan/ Semri Group and the Upper Vindhyan (figures 1 and 2). However, the exact stratigraphic position of the unconformity is still controversial. From previous studies carried out in the Bundelkhand 

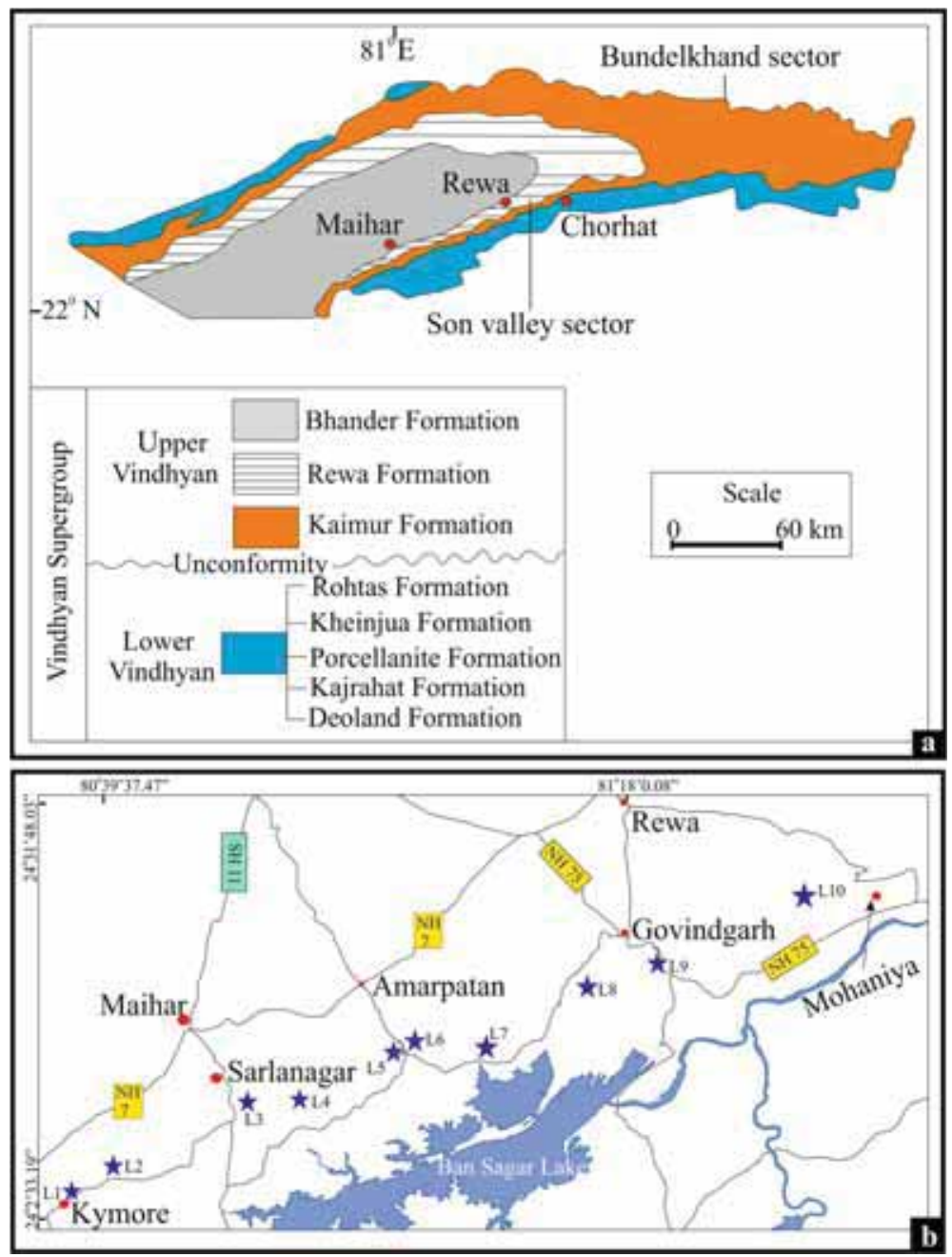

Figure 1. Lithological map of the Vindhyan Supergroup and stratigraphy of the Vindhyan Supergroup, central India (a). The location map of the studied area (marked by stars) in the Son valley sector, central India (b).

sector, the unconformity lying between the Lower and Upper Vindhyan has been considered above the Rohtas Limestone (the topmost succession of the Lower Vindhyan Group) and below the Sasaram Sandstone (equivalent to Lower Quartzite of the Kaimur Formation; Chakraborty 2006; figure 2). In contrast to this, most of the previous studies in the Son valley sector noted that the top part of the Rohtas Limestone gradually passes upward into the Bhagwar Shale which is composed of sand-silt alternations with a substantial amount of the volcanic input (figure 2; Banerjee 1974; Sastry and Moitry 1984; Chakraborty and Chaudhuri 1990; Bhattacharyya 1996; Chakraborty 2006; Kumar and Sharma 2011) and the unconformity between the Lower and Upper Vindhyan lies above this shale (figure 2). A claim has also been made that the arkosic/pebbly sandstone of the Sasaram Sandstone (also known as the
Lower Quartzite) observed above the unconformity in the Bundelkhand sector is absent in the Son valley sector (Chakraborty 2006).

Recent fieldwork in the Son valley sector along $\sim 150 \mathrm{~km}$ stretch from Mohaniyain in the east $\left(24^{\circ} 25^{\prime} 34.06^{\prime \prime} \mathrm{N}, 81^{\circ} 40^{\prime} 8.86^{\prime \prime} \mathrm{E}\right)$ to Kymore $\left(24^{\circ} 3^{\prime} 36.78^{\prime \prime} \mathrm{N}, \quad 80^{\circ} 36^{\prime} 31.53^{\prime \prime} \mathrm{E}\right)$ in the west (figure $1 \mathrm{~b}$ ) reveals the presence of a sandstone having a maximum thickness of $\sim 12 \mathrm{~m}$ immediately above the Rohtas Limestone with a sharp, undulating and erosional contact in between (figure 3). A thin (ca. $10 \mathrm{~cm}$ ), laterally persistent and sheet-like coarse-grained layer with chertified limestone clasts demarcates the erosional contact between the Rohtas Limestone and the sandstone (figures 2 and 4a). So far the sandstone had not been described and a detailed sedimentalogical study of this sandstone is non-existent. Possibly, this is the reason why most of the previous workers 


\begin{tabular}{|c|c|c|c|c|c|c|}
\hline & & $\mathrm{Fm}$. & \begin{tabular}{|c|}
$\begin{array}{c}\text { Eastem part of Son valley } \\
\text { sector (existing) }\end{array}$ \\
\end{tabular} & $\begin{array}{c}\text { Western part of Son } \\
\text { valley sector (existing) }\end{array}$ & $\begin{array}{l}\text { Proposed stratigraphy of } \\
\text { Son valley sector }\end{array}$ & Age $(\mathrm{Ma})$ \\
\hline & & & Upper Bhander Sandstone & $\begin{array}{l}\text { Upper Bhander } \\
\text { Sandstone }\end{array}$ & Upper Bhander Sandstone & \\
\hline & & & Sirbu Shale & Sirbu Shale & Sirbu Shale & $\begin{array}{l}625 \pm 25[\mathrm{~F}-\mathrm{T}] \text { Srivastava } \\
\text { and Rajagopalan, (1988) }\end{array}$ \\
\hline & & $\frac{\alpha}{\frac{1}{\theta}}$ & Lower Bhander Sandstone & $\begin{array}{l}\text { Lower Bhander } \\
\text { Sandstone }\end{array}$ & Lower Bhander Sandstone & \\
\hline & A & 啥 & Bhander Limestone & Bhander Limestone & Bhander Limestone & $\begin{array}{l}908 \pm 72[\mathrm{~Pb}-\mathrm{Pb}] \\
\text { Ray et al. (2002) } \\
1075-900[\mathrm{~Pb}-\mathrm{Pb}] \\
\text { Gopalan et al. (2013) }\end{array}$ \\
\hline & రิ & & Ganurgarh Shale & Ganurgarh Shale & Ganurgarh Shale & \\
\hline & $\approx$ & $\leqslant$ & Rewa Sandstone & Rewa Sandstone & Rewa Sandstone & \\
\hline & & $\frac{\sigma_{\alpha}}{\alpha}$ & Rewa Shale & Rewa Shale & Rewa Shale & $\begin{array}{l}1100-700 \text { Chauria-Tawuia } \\
\text { Rai et al. (1997) }\end{array}$ \\
\hline & 동 & & Dhandraul Sandstone & Dhandraul Sandstone & Dhandraul Sandstone & \\
\hline & & $\propto$ & $\begin{array}{c}\text { Scarp Sandstone/ } \\
\text { Mangeswar Sandstone }\end{array}$ & $\begin{array}{c}\text { Scarp Sandstone } \\
\text { Mangeswar Sandstone }\end{array}$ & $\begin{array}{c}\text { Scarp Sst./ } \\
\text { Mangeswar Sst. }\end{array}$ & \\
\hline & $\frac{\text { and }}{2}$ & 岁 & Bijaigarh Sh. & & & $1210 \pm 52[\mathrm{Re}-\mathrm{Os}]$ \\
\hline$\sum_{0}^{2}$ & 5 & $\sum_{3}^{3}$ & \begin{tabular}{c|} 
Ghaghar Sandstone \\
Upper Sandstone/Quartzite
\end{tabular} & & & Tripathy and Singh (2015) \\
\hline$\approx$ & & & \begin{tabular}{|l|} 
Susunia Breccia \\
\end{tabular} & & Bhagwar Shale/Silicified Shale & \\
\hline$\simeq$ & & & Silicified Shale & & & \\
\hline $\begin{array}{c}2 \\
\text { a } \\
\text { in }\end{array}$ & & UN & $\begin{array}{l}\text { Sasaram Sandstone } \\
\text { (Lower Quartzite) }\end{array}$ & & $\begin{array}{l}\text { Sasaram Sandstone } \\
\text { (Lower Quartzite) }\end{array}$ & \\
\hline $\begin{array}{l}z \\
\vdots \\
z \\
x \\
0\end{array}$ & & $\sum^{2}$ & Rohtas Limestone & Rohtas Limestone & Rohtas Limestone & $\begin{array}{l}\text { Chakraborti et al. (2007) } \\
1599 \pm 48[\mathrm{~Pb}-\mathrm{Pb}] \\
\text { Sarangi et al. (2004) } \\
1601 \pm 130[\mathrm{~Pb}-\mathrm{Pb}] \\
\text { Ray et al. (2003) }\end{array}$ \\
\hline$\frac{z}{>}$ & 灾 & $\bar{g}$ & Rampur Shale & Rampur Shale & Rampur Shale & $\begin{array}{l}1599 \pm 8 \text { [SHRIMP] } \\
\text { Rasmussen et al.(2002) } \\
1602 \pm 10[\text { SHRIMP] } \\
\text { Rasmussen et al.(2002) }\end{array}$ \\
\hline & $\bar{\Upsilon}$ & $\sum_{2}^{\vdots}$ & Chorhat Sandstone & Chorhat Sandstone & Chorhat Sandstone & \\
\hline & $\frac{n}{z}$ & $\frac{\text { 至 }}{\underline{x}}$ & Koldaha Shale & Koldaha Shale & Koldaha Shale & \\
\hline & $\frac{1}{\vdots}$ & & & & & $\begin{array}{l}1628 \pm 8 \text { [SHRIMP] } \\
\text { Rasmussen et al.(2002) } \\
1630.7 \pm 0.4[\mathrm{U}-\mathrm{Pb}] \\
\text { Ray et al.(2002) }\end{array}$ \\
\hline & $\frac{⿱}{\Delta}$ & & & PORCELLANITE & & 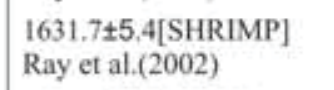 \\
\hline & ב & & & & & $\begin{array}{l}1640 \pm 4[" \mathrm{~Pb} / \mathrm{Pb}] \\
\text { Bickford et al.(2017) }\end{array}$ \\
\hline & & $\stackrel{5}{\vdots}$ & Kajrahat Limestone & Kajrahat Limestone & Kajrahat Limestone & $\begin{array}{l}1721 \pm 90[\mathrm{~Pb}-\mathrm{Pb}] \\
\text { Sarangi et al.(2004) }\end{array}$ \\
\hline & & $\underset{\sum}{\stackrel{5}{z}}$ & Arangi Shale & Arangi Shale & Arangi Shale & \\
\hline UN & & & & $\frac{\text { DEOLAND }}{\text { MAHAKOSHALGRO }}$ & & \\
\hline
\end{tabular}

UN-Unconformity; Fm.-Formation

Figure 2. Stratigraphy of the Vindhyan Supergroup, Son valley (modified after Auden 1933; Banerjee 1974; Rao and Neelakantam 1978; Sastry and Moitra 1984; Bhattacharyya 1996; Chakraborty 2006; Chakraborty et al. 2010; Kumar and Sharma 2011).

considered the Bhagwar Shale within the Lower Vindhyan/Semri Group and found that the unconformity is placed above it (Banerjee 1974;
Rao and Neelakantam 1978; Sastry and Moitry 1984; Bhattacharyya 1996; Chakraborty 2006; Valdiya 2010; Kumar and Sharma 2011). 


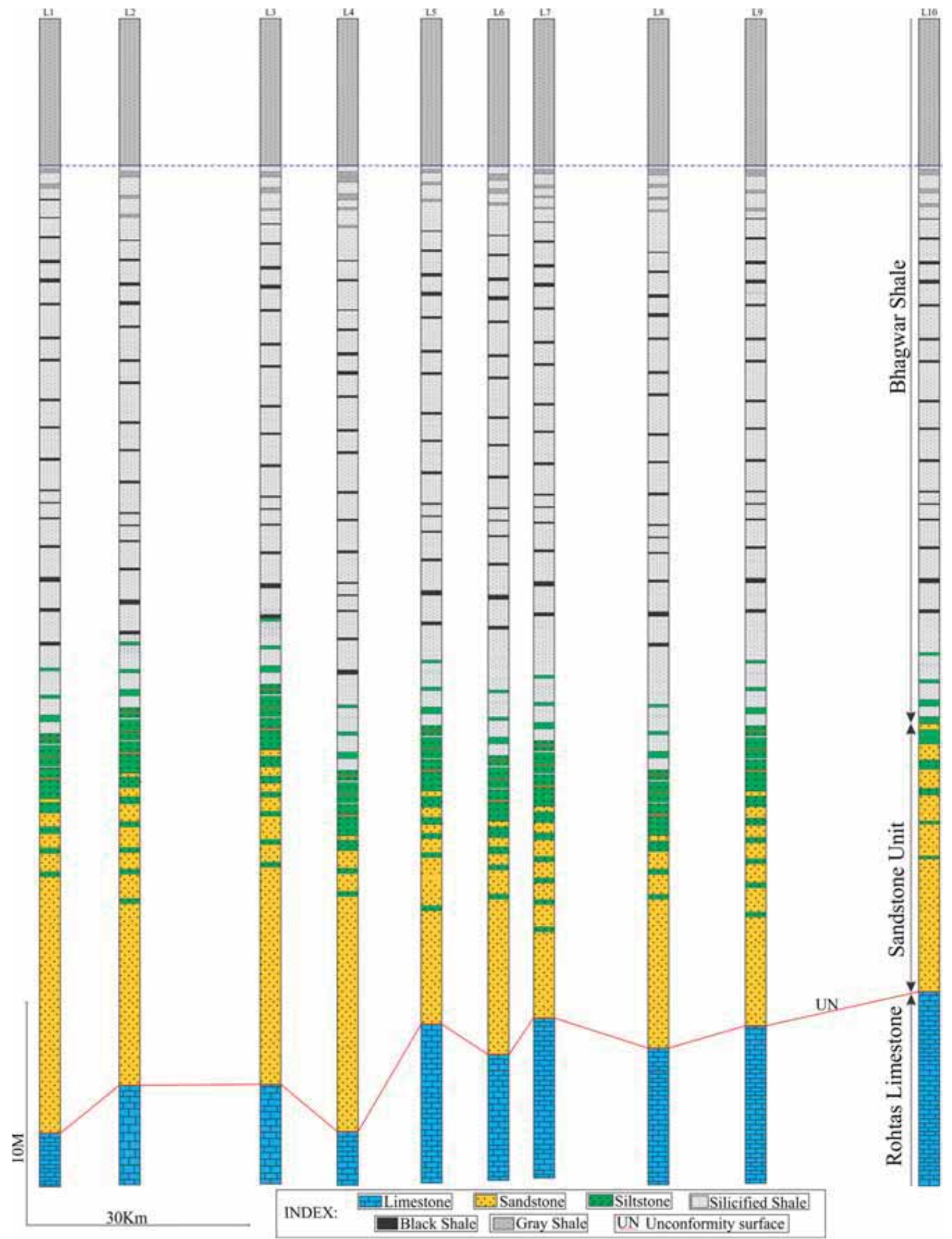

Figure 3. Stratigraphic sections across the boundary between the Lower and Upper Vindhyan along the studied stretch (marked in figure 1b). Note the unconformable relationship between the Rohtas Limestone and the overlying sandstone unit. Also note the gradational relationship between the sandstone and the overlying Bhagwar Shale. 

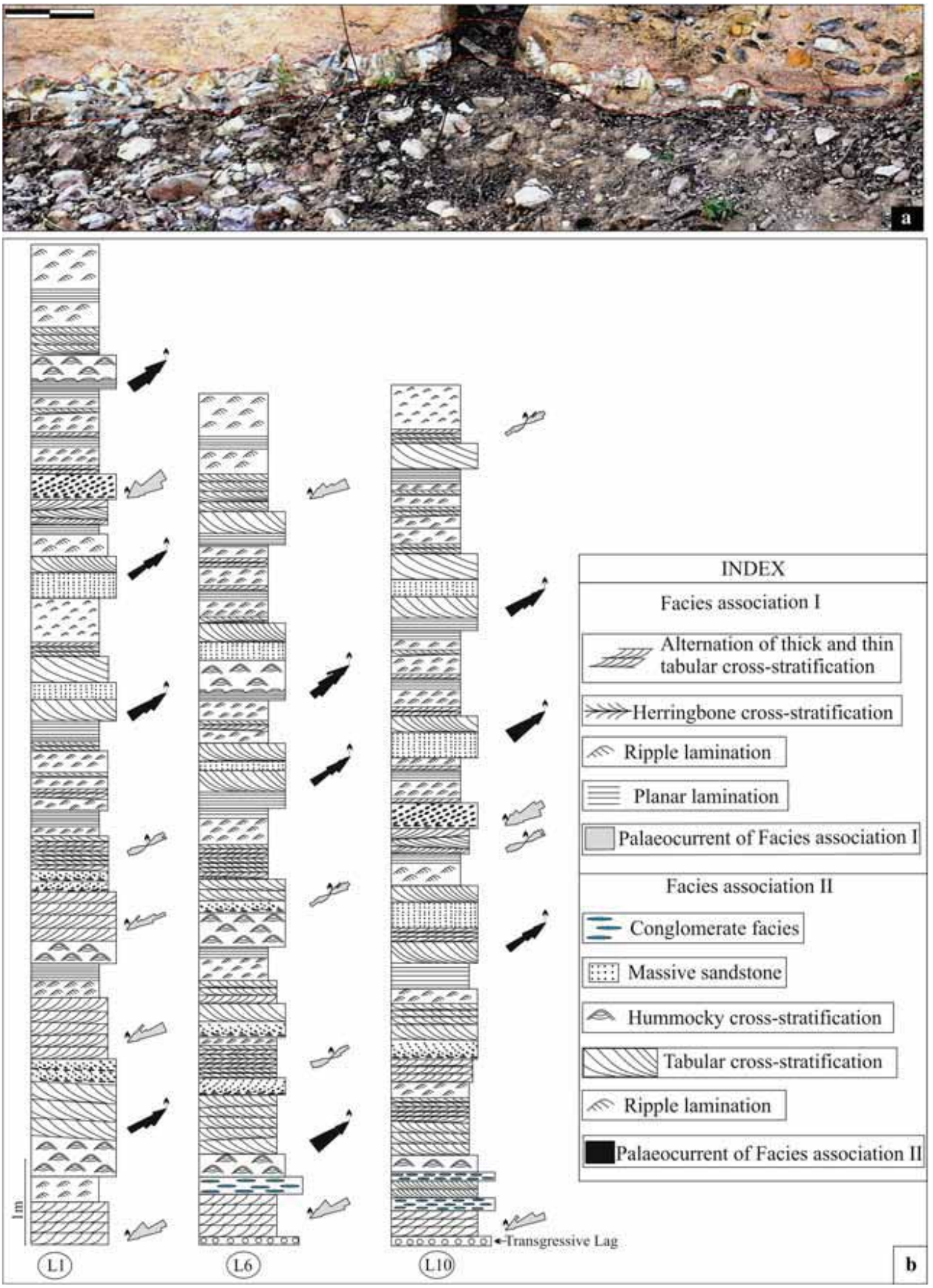

Figure 4. Transgressive lag present at the basal part of the sandstone (marked by dotted lines, bar length $20 \mathrm{~cm}$ ) (a). Distribution of the facies associations along with palaeocurrent directions of two facies associations in three best-exposed localities (b). 
The goal of the present paper is to revisit the boundary between the Lower and Upper Vindhyan in the Son valley sector and also to record the nature of this contact with the help of a detailed sedimentary facies analysis of this sandstone, hitherto undescribed.

\section{Geological background}

The Vindhyan basin, developed during the Palaeo to the Neoproterozoic time (Bose et al. 2001; Chakraborty et al. 2010), rests unconformably on the Aravalli craton, the Bundelkhand granitic gneiss and the Mahakoshal group of rocks. The Vindhyan rocks are distributed over $\sim 1,00,000 \mathrm{~km}^{2}$. The Vindhyan sediments are generally unmetamorphosed and only mildly deformed. The geophysical investigation has suggested the presence of the E-W trending faults that initiated the formation of the Vindhyan basin (Naqvi and Rogers 1987). The rifting was accompanied by a dextral shear which created some NW-SE elongated sub-basins where the sedimentation took place (Bose et al. 1997, 2001). As a result, strike-wise variations in both thicknesses of the constituting facies and sediment character changes are rapid in the Lower Vindhyan/Semri Group (Bose et al. 2001). Contrastingly, the Upper Vindhyan Group is laterally persistent, likely to be deposited in a sag basin (Chanda and Bhattacharyya 1982; Bose et al. 2001; Sarkar et al. 2002b). The beds are much steeper in the lower part compared to that of the upper part of the Vindhyan succession.

The Vindhyan sediments are divided into three outcrop sectors, namely, the Bundelkhand sector, Son valley sector and Rajasthan sector (Chakraborty 2006; Chakraborty et al. 2010). The Bundelkhand and Rajasthan sectors are dominated by carbonate sediments; the sediments in the Son valley sector are represented by both siliciclastic and carbonate sediments in nearly equal volume (Chakraborty 2006; Chakraborty et al. 2010). The Son valley Vindhyan has a maximum thickness of $4.5 \mathrm{~km}$. They are constituted by two groups, the Lower Vindhyan/Semri Group and the Upper Vindhyan Group separated by a basin-wide unconformity (figures 1a and 2; Kumar 1978a, b; McMenamin et al. 1983; Chakraborty and Bose 1992a, b; Chakraborty 1993; Bose et al. 2001; Schieber et al. 2007; Paikaray et al. 2008; Pati et al. 2008; Raza et al. 2010; Sallstedt et al. 2018). Five Formations are present (Deoland, Kajrahat, Porcellanite, Kheinjua and Rohtas) within the Lower Vindhyan Group while there are three Formations (Kaimur,
Rewa and Bhander) present within the Upper Vindhyan Group (Kumar 1978a, b; McMenamin et al. 1983; Chakraborty and Bose 1992a, b; Chakraborty 1993; Bose et al. 2001; Schieber et al. 2007; Paikaray et al. 2008; Pati et al. 2008; Raza et al. 2010; Sallstedt et al. 2018). The age of the Vindhyan Supergroup ranges from 1721 to 650 ma (Chakraborty et al. 2010 and references there in; Gopalan et al. 2013; Tripathy and Singh 2015; Bickford et al. 2017). Dominant lithologies of the Supergroup are mature sandstone, shale, carbonate and conglomerate, mostly intra-formational. The dominance of a shallow marine depositional regime has been considered mostly (Singh 1973; Banerjee 1974; Chanda and Bhattacharyya 1982; Prasad and Verma 1991) with a range of variation from the barrier bar-lagoon, tidal and beach to a relatively deeper part of the shelf (Chakraborty and Bose 1992a, b; Chakraborty 1995; Bose et al. 2001; Sarkar et al. 1996, 2002a, b). On the other hand, subordinate amounts of fluvial and aeolian deposits have also been reported from the supergroup (Bhattacharyya and Morad 1993; Bose and Chakraborty 1994; Bose et al. 1999; Chakraborty and Chakraborty 2001).

\section{Stratigraphic problem}

The Bhagwar Shale is well exposed in parts of the Son valley sector (figure 3). The Bhagwar Shale composed of sand-silt alternations with a substantial amount of the volcanic input (Chakraborty 2006; figure 3). The shale is well exposed along the studied stretch (figure 1b). A persistent sandstone layer is present below the shale (figure 3). The upper contact of the sandstone with the Bhagwar Shale is gradational while the lower contact of the sandstone is sharp and undulatory with the underlying Rohtas Limestone (figure 3). The contact of the Bhagwar Shale is also gradational with the overlying Kaimur Formation. The colour of the shale varies from grey to dark grey, even black at places, both vertically as well as laterally. The sand/silt stringers present within the shale are laterally continuous. Some laterally persistent sand layers with sole features at their bases are present within the shale. Very fine-grained tuff layers are also present within the Bhagwar Shale (see figure in Chakraborty et al. 1996). As discussed, the sandstone below the Bhagwar Shale is directly overlying the Rohtas Limestone (figures 3 and $4 \mathrm{a}$ ) and here lies the problem of placing the boundary between the Lower and Upper Vindhyan in this 
sector. So far, in most of the studies, the boundary has been demarcated above the Bhagwar Shale which shows a gradational boundary with the overlying Mangeswar/Scrap Sandstone of Kaimur Formation. However, the sandstone lying below the Bhagwar Shale has not been reported earlier in the Son valley sector, and hence, demands a detailed study before considering the contact between the Lower and the Upper Vindhyan.

\section{Facies analysis of the sandstone present immediately above the Rohtas Limestone}

Deposition of the Semri/Lower Vindhyan Group ends with a ca. $110 \mathrm{~m}$ thick Rohtas Limestone (topmost part of the Rohtas Formation). The upper part of the Rohtas Limestone is chertified in many places (figure 4a). The Rohtas Limestone in the Son valley sector is overlain by ca. $12 \mathrm{~m}$ thick sandstone unit (figures 3 and $4 \mathrm{~b}$ ). The boundary between the Rohtas Limestone and the overlying sandstone is sharp, erosional and demarcated by a thin $(\sim 10 \mathrm{~cm})$ sheet-like unit containing pebbles of chertified limestone (av. clast size $5 \mathrm{~cm}$ ) at several places in the study area (figure 4a). Possibly, these pebbles are derived from the upper part of the chertified Rohtas Limestone.

This sheet-like pebble-bearing unit is followed upward by a laterally persistent sandstone unit (max. thickness $12 \mathrm{~m}$ ) along with an $\sim 150 \mathrm{~km}$ east-west stretch of the study area (figure 1b). The overall grain size of this sandstone varies from coarse to fine sand. Considering the primary sedimentary structures, sediment composition and bed geometry, the sandstone can be subdivided into two facies associations: (a) Facies association I and (b) Facies association II (figure 4b). The constituting facies of Facies association $I$ is in general of fine to medium size sandstone and also rich in mud compared to that of Facies association II. As mentioned earlier, the details regarding this sandstone unit are not available in the literature, so we thought it is a pre-requisite to discuss this sandstone in detail before finalising the boundary between the Lower and the Upper Vindhyan in the Son valley. The following are the detailed description and interpretations for each facies association of the sandstone.

\subsection{Facies association I}

Facies association I is distinctly different from the Facies association II with respect to the grain size (varying from medium to fine sand) and mud content. This Facies association I is dominantly cross-stratified in nature and consists of the following four facies.

\subsubsection{Alternation of thick and thin tabular cross-stratified sandstone facies}

This facies comprises medium- to fine-grained sandstone exhibiting unidirectional cross-stratification. It is present at the basal part of the sandstone and lies exactly on top of the basal thin and sheet-like pebble-bearing unit (marked by dotted lines in figure $4 \mathrm{a}$ ). The average thickness of the facies is $15 \mathrm{~cm}$. Internally, the crossstratifications are characterised by an alternation of thick and thin planar tabular cross-strata (figure 5a), the foreset bundles are separated by mudstone partings (figure 5a). The thickness of the individual foreset varies between 0.5 and $3.2 \mathrm{~cm}$, whereas the mudstone laminae are a few sub-millimetres thick. The thickness measurement of cross-set bundles reveals a nearly symmetrical pattern of cyclicity (figure 5b). A maximum of 28 laminae occurs between two successive peaks of the thick laminae (figure 4b). Usually, the foreset dip decreases from the highest peak to the trough of the sinuous curve. The dips of the cross-sets decrease down current from ca. $30^{\circ}$ to ca. $15^{\circ}$ and laterally pass over into compound cross-stratification at times (marked in figure 5c; Rouse 1961; Bose et al. 1997). Some of the foresets are defined by mud clasts (figure 5d). At places, thick mud drapes (up to $2 \mathrm{~cm}$ ) occur within the cross-lamina set (figure $5 \mathrm{c}$ ). Small-scale cross-lamina (ca. $3 \mathrm{~cm}$ thick) dipping oppositely is occasionally present within the larger foreset of the cross-bedding (marked in figure $5 \mathrm{c}$ ).

\subsubsection{Herringbone cross-stratified sandstone facies}

Two sets of oppositely dipping cross-strata separated by a gently inclined, planar erosional surface constituting a herringbone pattern is another facies of this association (figure $5 \mathrm{e}$ ). The average thickness of this facies is $30 \mathrm{~cm}$. The orientation of the herringbone cross-strata shows a distinct bipolar and bimodal palaeocurrent direction all over the studied stretch (figure 5f). Double mud drape is a characteristic feature of the foresets (figure $5 \mathrm{~g}$ ). Mud clasts 

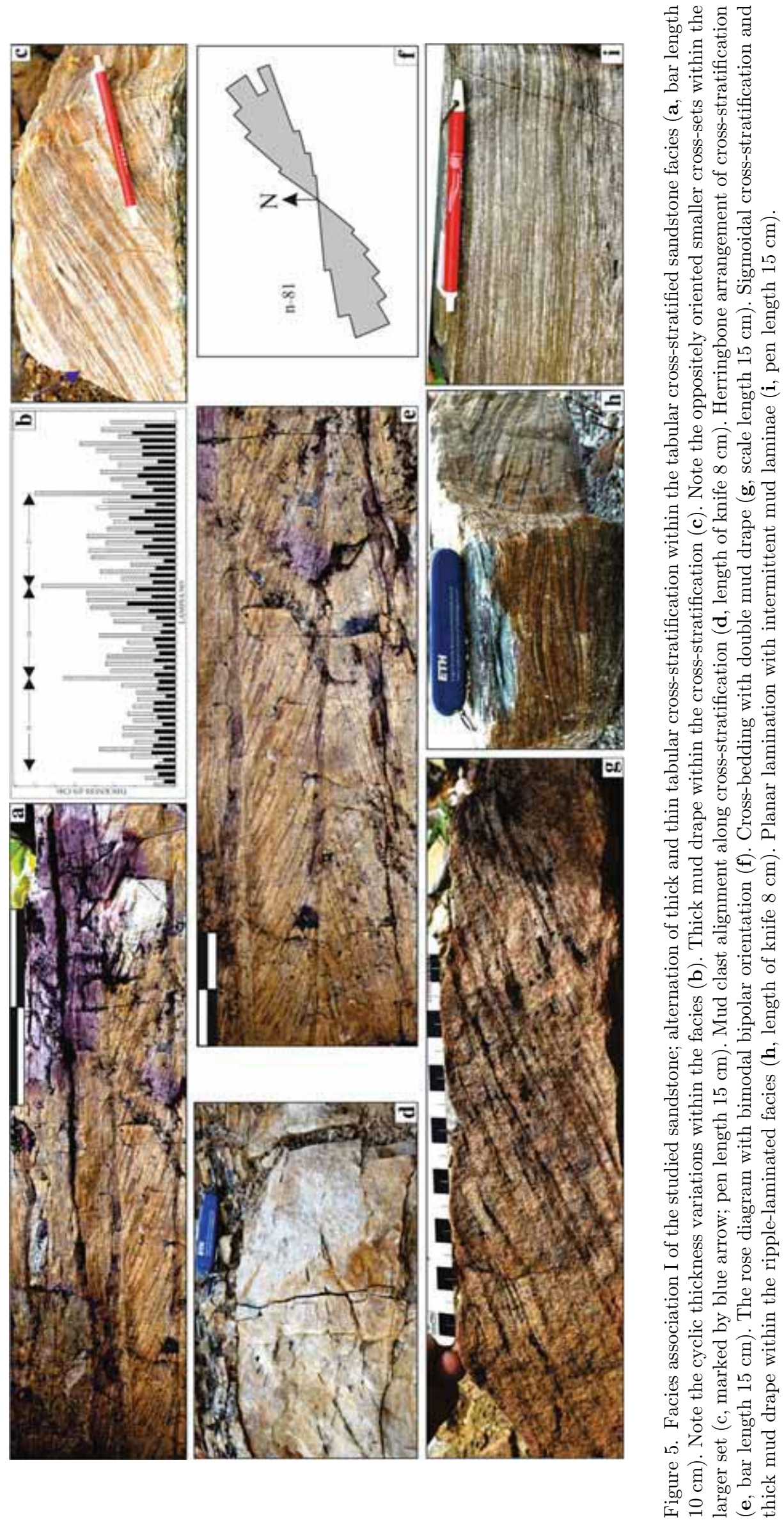
are present along the boundary between two differently oriented sets of cross-stratification at places (figure 5d).

\subsubsection{Small-scale ripple-laminated sandstone facies}

This facies is characterised by small-scale ripplelaminated sandstone and is commonly associated with the facies 4.1 .1 (figure $5 \mathrm{~h}$ ). Mud is present at the trough of some of the ripples (figure $5 \mathrm{~h}$ ). The maximum thickness of the ripple foreset is $5 \mathrm{~cm}$. Thick mud partings occur at the ripple set boundaries (figure 5h). Ripple cross-lamina exhibits sigmoidal patterns at places (figure $5 \mathrm{~h}$ ).

\subsubsection{Planar-laminated sandstone facies}

Parallel laminated sandstone with intermittent mud laminae defines this facies (figure 5i). The average thickness of the facies is $20 \mathrm{~cm}$. The facies exhibits vertical variations in lamina thickness (ca. $2 \mathrm{~cm}$ for sand lamina and $0.3 \mathrm{~cm}$ for mud lamina) (figure 5i). However, limited exposure does not permit the measurement of the thickness of sufficient numbers of laminae.

Interpretation: The presence of a thin lag between the Rohtas Limestone and the sandstone unit possibly represents a transgressive lag (Catuneanu 2006; Mandal et al. 2016). The presence of the transgressive lag along the boundary of the Rohtas Limestone and this sandstone indicates a fresh episode of sedimentation after the completion of the Lower Vindhyan sedimentation. The internal structures of sandstone, cyclicity in laminae thickness and high concentration of mud within all the constituting facies of the Facies association I indicate the tide-dominated depositional setting. The bed-load movement under the influence of dominant unidirectional current during the tidal regime is inferred. The alternations between the thick and thin foresets strongly support tidal actions. Bipolar and bimodal palaeocurrent directions (figure 5f) of herringbone patterned cross-stratified sandstone facies corroborates tidal actions (Visser 1980; De Boer et al. 1989; Bose et al. 1997). The presence of double mud drapes within this facies (figure 5g) indicates a subtidal environment (Visser 1980; Bose et al. 1997; Eriksson and Simpson 2004; Kohsiek and Terwindt 1981). The larger cycle, measured from alternating thick-thin laminae (figure 5b), is very much compatible with the lunar bi-monthly (spring to spring) cycle. This can readily be attributed to semidiurnal tides. The intra-set cyclic variations along with grain size indicate repeated waxing and waning of the water flow. In contrast to the bidirectional palaeocurrent pattern, alternating thick-thin tabular cross-stratified sandstone facies (facies 4.1.1) is unidirectional (figure 5c), indicating flow reversal during the abandoning phase of the tidal sand-waves (Nio and Yang 1991; Bose et al. 1997). In some places, mud laminae within the constituting facies are very thick (figure 5c). Such thick mud drapes in between the sand layers rarely form at any stage of the tidal cycle (McCave 1985; Chakraborty and Bose 1990). However, thick mud can be introduced to any tidal system from the outside by a process which is able to disperse mud in a suspension load from the shoreline environments, possibly by a super-storm event (Allen 1988; Chakraborty and Bose 1990). High-suspended sediment concentration may lead to the deposition of a thick mud layer during the neap period as well (Schieber 1986).

\subsection{Facies association II}

This association occasionally interferes with Facies association I. However, Facies association II, characteristically contains less mud compared to Facies association I. Facies association II primarily consists of coarse- to fine-grained sandstone. Five facies comprising Facies association II are discussed as follows:

\subsubsection{Conglomerate facies}

This facies occurs locally and is characterised by a matrix-supported conglomerate unit having a wedge-shaped geometry with a maximum thickness of $\sim 40 \mathrm{~cm}$. The base of the facies is invariably sharp and scoured (figure 6a). The compositions of clasts include chertified limestone, vein quartz and sandstone (figure $6 \mathrm{a}$ and $\mathrm{b}$ ). The maximum size of the clasts is $11 \mathrm{~cm}$. The interstitial spaces between the clasts of the conglomerate are filled with a coarse-grained sandy matrix (figure 6a). This conglomerate facies often grades into a massive sandstone laterally and vertically (figure 6a).

\subsubsection{Massive sandstone facies}

This facies is characterised by massive, coarse- to medium-grained sandstone beds (thickness of the 

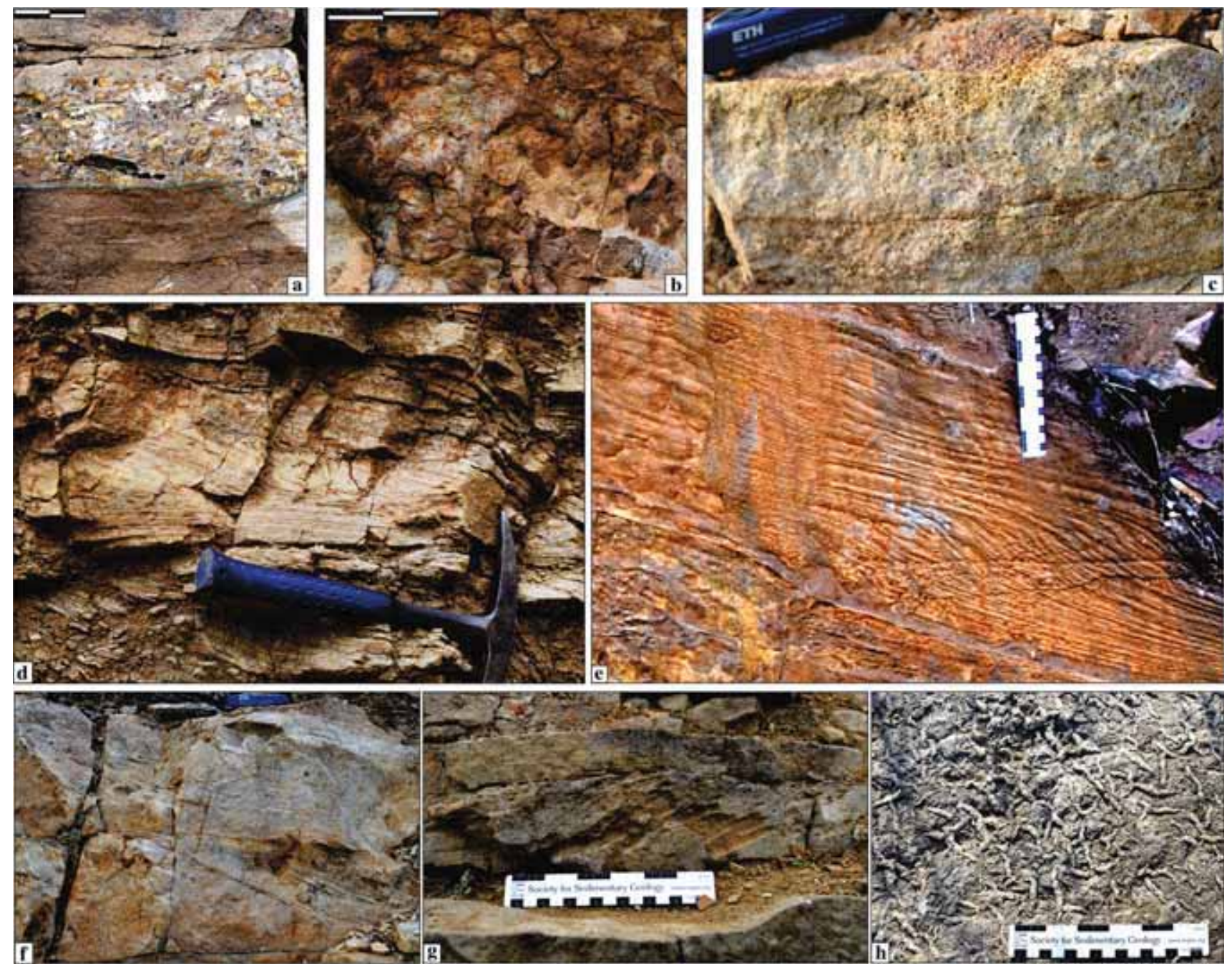

Figure 6. Facies association II; conglomerate facies (a, bar length $10 \mathrm{~cm}$ ). Note the scoured base (marked by dotted lines) and upward gradation into massive sandstone. Sand clasts on the bedding plane surface (b, bar length $15 \mathrm{~cm}$ ). Massive sandstone facies (c, length of knife $8 \mathrm{~cm}$ ). The transition from planar to cross-lamination (d, hammer length $35 \mathrm{~cm}$ ). Brink point maintaining the same level from the base within cross-stratification, massive sandstone facies (e, scale length $15 \mathrm{~cm}$ ). Amalgamated cross-stratified facies (f, length of knife $8 \mathrm{~cm}$ ). Hummocky cross-stratified facies (g, scale length $15 \mathrm{~cm})$. Syneresis cracks on the bedding surface $(\mathbf{h}$, scale length $15 \mathrm{~cm})$.

facies is $\sim 20 \mathrm{~cm}$ ) (figure $6 \mathrm{c}$ ). The base of the facies is sharp than its top. Gutters, bipolar prod marks and local flutes are present at the sole of this facies. The massive beds often grade upward into planar laminated beds followed by cross-stratifications (figure 6d). The overall grain size of the facies decreases upward. Mud clasts are common at the base of the massive beds as well as along the crossstratifications. The style of cross-stratification within a set changes laterally but non-cyclically. The brink point of the cross-stratifications maintains nearly the same distance from the base (figure 6e). The top of the sandstone beds is invariably waverippled (figure $4 \mathrm{~b}$ ). The ripple crests are straight in nature, having local bifurcations, although discernible asymmetry is common in their profiles.

\subsubsection{Tabular cross-stratified amalgamated sandstone facies}

This facies is characterised by amalgamated sandstone beds (figure 6f). The maximum thickness of the individual bed is ca. $32 \mathrm{~cm}$ but amalgamation may contribute to a thickness up to $1 \mathrm{~m}$. Internal tabular cross-stratifications define the amalgamated sand beds (figure 6f). The palaeocurrent direction measured from these tabular cross-strata is directed towards the WSW direction (figure 4b). It is commonly associated with massive to feebly graded sandstone facies and hummocky cross-stratified sandstone facies (figure $4 \mathrm{~b}$ ). The bases of the facies are sharp while their tops are gradational with the occasional presence of wave-ripple laminations. 


\subsubsection{Hummocky cross-stratified sandstone facies}

This facies is characteristically medium- to finegrained, moderately sorted sandstone with broadly lenticular to tabular beds and convex-up tops (figure $6 \mathrm{~g}$ ). It is overlain by wave-ripple laminated facies (figure 4b) with less sharp contact. Hummocks and swales are frequently observed with the maximum height and wavelength ca. 8 and $35 \mathrm{~cm}$, respectively. Bases of such beds generally replicate the underlying bed surface. Hence the bases are sharp but non-erosional, whereas the top of the beds is less sharp. This facies is commonly associated with the top part of the massive sandstone facies. Overall normal gradation is observed within the facies.

\subsubsection{Wave-ripple laminated sandstone facies}

This wave-ripple laminated sandstone facies generally overlies the top of the preceding facies. Ripple crests are straight and show bifurcations on the bedding plane. Syneresis cracks are abundantly present on the bed surfaces of these beds at different levels (figure 6h). Overall orientations of these cracks are fairly consistent but vary widely between beds (Pratt 2002).

Interpretation: The stacking pattern of beds within the facies of this association reveals occasional interruptions by high-energy events like storms within a tide-dominated environment. The massive sandstone facies indicates rapid dumping of the sediments. The massive character and absence of normal grading indicate deposition from shortlived, high-density flows. The high rate of sedimentation prevents the sorting process (Kneller and Branney 1995; Magalhães et al. 2015). The vertical and lateral transitions of conglomerate facies to massive sandstone indicate the deposition of both the component from a single flow. The scoured base of the conglomerate beds (figure 6a) at places indicates the presence of turbulence within the flow. The flow must have enough capacity to pick-up chertified limestone clasts from the topmost part of the Rohtas Limestone. The occurrence of amalgamated-sandstone beds within Facies association II, juxtaposed one above the other suggests the rapid recurrence of event flow, possibly storm surges, in a high-flow regime (Sarkar et al. 2004). The individual sandstone bed comprising amalgamated-sandstone facies indicates the product of a single depositional continuum over a relatively short time. A sharp irregular base with sole features also supports the high-energy events responsible for the deposition of the beds and the supercritical nature of the initial flow (Sarkar et al. 2012). The cross-stratification having brink points at the same height from the base suggests the high rate of sand fall-out from suspension possibly during the periods of a heavy storm. The steady upward decline in both grain-size and flow regime suggests a gradual waning of the high-energy events (Bose and Sarkar 1991). Preserved-wave ripple forms on the bedding surface and hummocky cross-stratified sandstone facies reflect deposition under the influence of the oscillatory flow, possibly during storm surges. Asymmetry in the ripple profiles indicates the simultaneous presence of a tractive force within the flow. Deposition from storm-generated combined, wave-cum-current, flow is thus inferred. Syneresis cracks present on the bed-surfaces of wave-ripple laminated sandstone facies possibly originate through the dewatering of the sandy beds due to the rapid deposition of the overlying sediment (Kidder 1990). Increased porewater pressure because of storm wave action (Cowan and James 1992; Harazim et al. 2013; McMahon et al. 2017) may be responsible for the generation of syneresis cracks.

\section{Discussion}

The Rohtas Limestone is the topmost unit of the Lower Vindhyan succession. The limestone is overlain by laterally persistent sandstone in the studied stretch of the Son valley (figures 3 and 7). The sandstone is deposited on an undulating surface over a transgressive lag formed on the top surface of the Rohtas Limestone. The majority of the clasts are present within the lag derived from the Rohtas Limestone. The majority of the limeclasts are chertified. The topmost part of the Rohtas Limestone is also chertified at places. The degree of chertification also varies laterally to a remarkable extent. The chertified layers thus often appear to have irregular geometry and boundaries difficult to trace. Often they appear laterally discontinuous. Only exposure or near-exposure on the Earth's surface can account for this much abundance of silica during post-depositional alteration or weathering of the limestone. It is likely that part of the Rohtas Limestone was exposed for a long period of time which helps chertification (Kolodny et al. 1980). However, the transgressive lag indicates a fresh sedimentation event. The sedimentation started on a tide-dominated shelf. The 


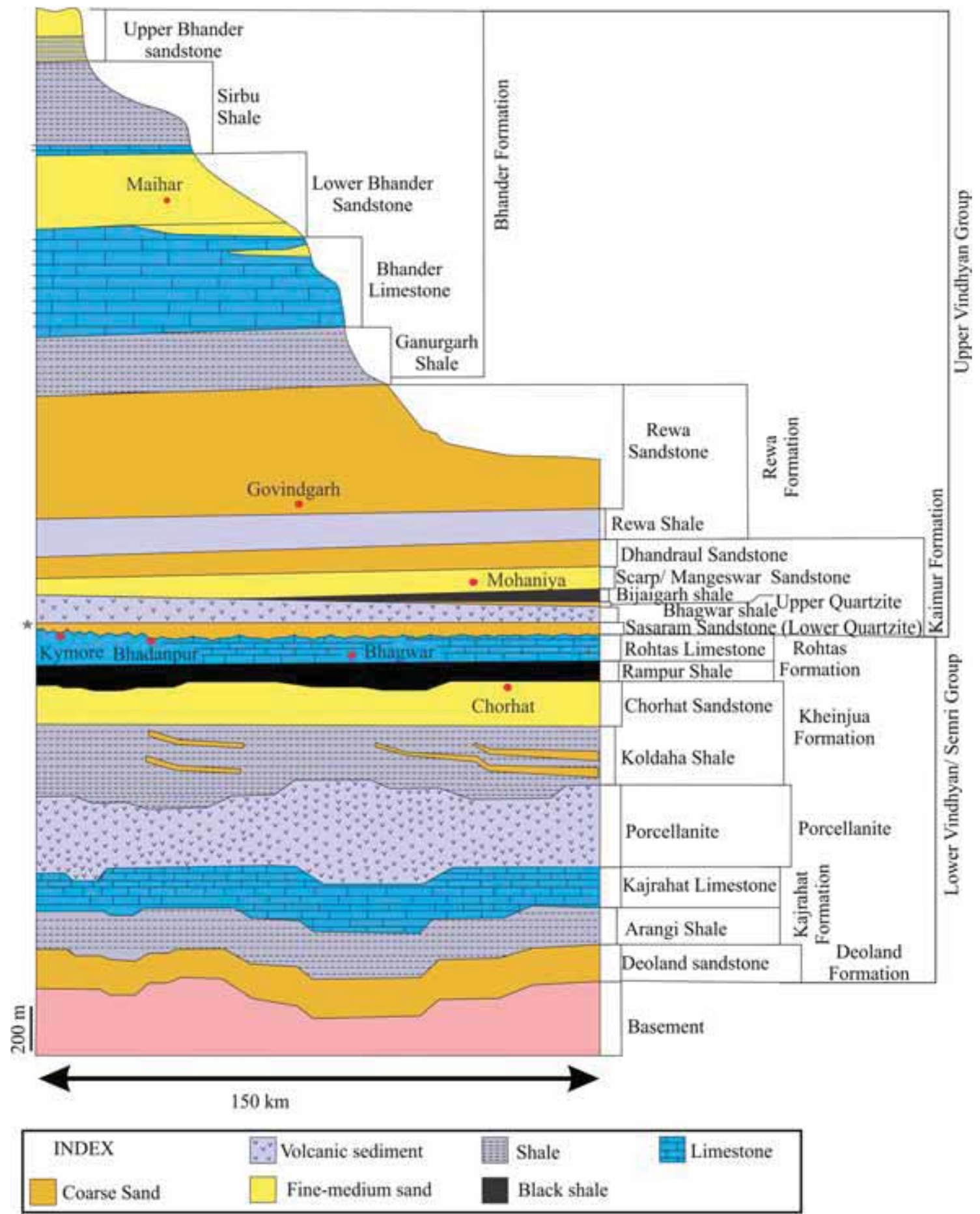

Figure 7. Stratigraphic column of the Vindhyan Supergroup present in the Son valley, central India (modified after Chakraborty 2006). Note the laterally persistent sandstone unit present above the Rohtas Limestone with an erosional surface in-between, traced from Mohaniya to Kymore.

presence of thick-thin alternation, double mud drape layers, herringbone cross-stratification, reactivation surface and frequently mud lamina within the cross-strata bear tell-tale evidence of tide domination. This tide-dominated environment intervened by storm is evidenced by the presence of hummocky cross-stratification, an amalgamation of sandstone beds and conglomerates/massive beds with sole features. The presence of numerous sandclasts within the Facies association II supports the influence of microbiota that turned sand into a cohesive sediment (Sarkar et al. 2014, 2018). The vertical transition of the facies assemblages rules out any major palaeogeographic shift. Some of 
them indicate clear evidence of subtidal deposition while a shallow marine depositional environment can be inferred from the sandstone unit in general. This sandstone unit is gradationally overlain by a shale unit known as Bhagwar Shale, also laterally persistent over the studied area (figure 7).

The boundary between the Lower and the Upper Vindhyan should be placed below the sandstone unit that indicates a change from a carbonate depositional system of Rohtas Limestone to a siliciclastic regime. The presence of a transgressive lag, consisting of pebbles of chertified limestone supports the initiation of a sedimentation event after a considerable gap. This sandstone deposited above the Rohtas Limestone is likely to be the equivalent of the Sasaram Sandstone (Lower Quartzite Member of the Kaimur Formation) reported from the Bundelkhand sector of the Vindhyan basin (Chakraborty 2006; Chakraborty et al. 2010). The depositional milieu of the newly studied sandstone resembles that of Sasaram Sandstone (Chakraborty and Bose 1990). After considering the detailed study in this part of the Son valley sector, it seems the boundary between the Upper and the Lower Vindhyan has not been placed properly (figures 2 and 7). Rather it will be more logical to put the boundary between the same at the base of the newly discovered sandstone which is the equivalent of the Sasaram Sandstone (Lower Quartzite).

\section{Conclusions}

1. The two-tier stratigraphic subdivision of the Vindhyan Supergroup, namely, the Lower and Upper Vindhyan is well established in the literature. The unconformity separating the Lower and Upper Vindhyan is placed above the Rohtas Limestone Member in the Bundelkhand sector. However, in the Son valley sector, it is placed above the Bhagwar Shale, a sandstone-shale heterolithic unit. Our study, therefore, contradicts the existing view regarding a gradational transition between the Rohtas Limestone and the overlying Bhagwar Shale.

2. Revisiting contact relationship between the Bhagwar Shale and Rohtas Limestone with the employment of process-based facies analysis, the present study documents a $\sim 12 \mathrm{~m}$ thick laterally persistent sandstone unit, hitherto undescribed, directly above the Rohtas Limestone with a sharp, erosional contact. The sandstone gradationally passes upward to the sensu-stricto Bhagwar Shale.

3. The presence of a transgressive lag dominantly consists of chertified lime clasts picked up from the long-exposed Rohtas Limestone surface, at the basal part of the sandstone unit bears telltale evidence for the initiation of a new sedimentation regime with transgression on the unconformable surface.

4. From the interpretation of depositional processes, a shallow-marine, subtidal environment is suggested for the sandstone unit. Possibly a tide-dominated shelf condition developed with transgression, occasionally intervened by storm. Similar sedimentation history also recorded from the Sasaram Sandstone (i.e., Lower Quartzite member of the Kaimur Formation) that overlies the Rohtas Limestone in the Bundelkhand sector.

5. The process-based appraisal indicates that sedimentation starts with a laterally persistent sandstone above the unconformable surface of Rohtas Limestone. The sandstone, in turn, gives way upward to the Bhagwar Shale.

6. The contact between the Lower and the Upper Vindhyan in the Son valley should be placed below the sandstone described in this work and not above the Bhagwar Shale.

\section{Acknowledgements}

The authors acknowledge the infrastructure support provided by their host institutes. SM acknowledges the UGC; AC, the DST Inspire Faculty programme; IM, the CSIR for providing a research grant and SS, the CAS (Phase VI), Department of Geological Sciences, JU for funding the fieldwork.

\section{References}

Allen J R L 1988 Reworking of muddy intertidal sediments in the Sevem Estuary, southwestern UK - a preliminary survey; Sedim. Geol. 50 1-23.

Auden J B 1933 Vindhyan sedimentation in Son valley, Mirzapur District; Geol. Surv. India Memoir 62 141-250.

Banerjee I 1974 Barrier coastline sedimentation model and the Vindhyan example; In: Contribution to earth and planetary sciences (ed.) De A, Quart. J. Geol. Min. Met. Soc. India 62 101-127.

Banerjee S, Bhattacharya S K and Sarkar S 2006 Carbon and oxygen compositions of the carbonate facies in the 
Vindhyan Supergroup, central India; J. Earth Syst. Sci. 115 113-134.

Bengtson S, Belivanova V, Rasmussen B and Whitehouse M 2009 The controversial 'Cambrian' fossils of the Vindhyan are real but more than a billion years older; Proc. Nat. Acad. Sci. USA 106 7729-7734.

Bengston S, Sallstedt T, Belivanova V and Whitehouse M 2017 Three-dimensional preservation of cellular and subcellular structures 1.6 billion-year-old crowd-group red algae; $P L o S$ Biol., https://doi.org/10.1371/journal.pbio.2000735.

Bhattacharyya A 1996 Recent advances in Vindhyan geology; Geol. Soc. India, 331p.

Bhattacharyya A and Morad S 1993 Proterozoic braided ephemeral fluvial deposits: An example from the Dhandraul sandstone formation of the Kaimur Group, Son Valley, central India; Sedim. Geol. 84 101-114.

Bickford M E, Mishra M, Mueller P A, Kamenov G D, Schieber J and Basu A $2017 \mathrm{U}-\mathrm{Pb}$ age and Hf Isotopic compositions of magmatic zircons from a rhyolite flow in the Porcellanite formation in the Vindhyan Supergroup, Son Valley (India): Implications for its tectonic significance; J. Geol. 125 367-379.

Bose P K and Sarkar S 1991 Basinal autoclastic mass flow regime in the Precambrian Chanda limestone formation, Adilabad, India; Sedim. Geol. 73 299-315.

Bose P K and Chakraborty P 1994 Marine to fluvial transition: Proterozoic upper Rewa Sandstone, Maihar, India; Sedim. Geol. 89 285-302.

Bose P K, Banerjee S and Sarkar S 1997 Slope-controlled seismic deformation and tectonic framework of deposition: Koldaha Shale, India; Tectonophys. 269 151-169.

Bose P K, Chakraborty S and Sarkar S 1999 Recognition of ancient eolian longitudinal dunes; a case study in upper Bhander Sandstone, Son valley, India; Int. J. Sedim. Res. 69 86-95.

Bose P K, Sarkar S, Chakrabarty S and Banerjee S 2001 Overview of Meso- to Neoproterozoic evolution of Vindhyan Basin, central India; Sedim. Geol. 141-142 395-419.

Bose P K, Sarkar S, Das N G, Banerjee S, Mandal A and Chakraborty N 2015 Proterozoic Vindhyan Basin: Configuration and evolution; In: Precambrian basins of India: Stratigraphic and tectonic context (eds) Mazumder R and Eriksson P G, Geol. Soc. London Memoir 43(1) 85-102.

Catuneanu O 2006 Principles of sequence stratigraphy; Elsevier, Amsterdam, 375p.

Chakraborty C 1993 Morphology, internal structure and mechanics of small longitudinal (seif) dune in an Aeolian horizon of the Proterozoic Dhandraul Quartzite, India; Sedimentology 40 79-85.

Chakraborty C 1995 Gutter casts from the Proterozoic Bijaygarh Shale formation, India: Their implication for storm-induced circulation in shelf settings; Geol. J. 30 69-78.

Chakraborty C 2006 Proterozoic intracontinental basin: The Vindhyan example; J. Earth Syst. Sci. 115 3-22.

Chakraborty C and Bose P K 1990 Internal structures of sand waves in a tide-storm interactive system: Proterozoic lower quartzite formation, India; Sedim. Geol. 67 133-142.

Chakraborty T and Chaudhuri A K 1990 Stratigraphy of Proterozoic Rewa group and palaeogeography of the Vindhyan Basin in central India during Rewa sedimentation; J. Geol. Soc. India 36 383-402.
Chakraborty C and Bose P K 1992a Rhythmic shelf storm beds: Proterozoic Kaimur formation, India; Sedim. Geol. 77 259-268.

Chakraborty C and Bose P K 1992b Ripple/dune to upper stage plane bed transition: Some observations from the ancient record; Geol. J. 27 349-359.

Chakraborty P P, Banerjee S, Das N G, Sarkar S and Bose P K 1996 Volcaniclastics and their sedimentological bearing in Proterozoic Kaimur and Rewa Groups in central India; Mem. Geol. Soc. India 96 59-75.

Chakraborty T and Chakraborty C 2001 Eolian-aqueous interactions in the development of a Proterozoic sand sheet: Shikaoda formation, Hosangabad, India; J. Sedim. Res. 71 107-117.

Chakraborty P P, Dey S and Mohanty S P 2010 Proterozoic platform sequences of Peninsular India: Implications towards basin evolution and supercontinent assembly; J. Asian Earth Sci. 39 589-607.

Chakraborty P P, Sarkar S and Patranabis-Deb S 2012 Tectonics and sedimentation of Proterozoic Basins of Peninsular India; Proc. Indian Nat. Sci. Acad. $\mathbf{7 8}$ 393-400.

Chanda S K and Bhattacharyya A 1982 Vindhyan sedimentation and palaeogrography; post-Auden development; In: Geology of Vindhyachal (eds) Valdiya K S, Bhatia S B and Gaur V K, Hind. Publ. Corp. (India), Delhi, pp. 88-101.

Cowan C A and James N P 1992 Diastasis cracks: Mechanically generated synaeresis-like cracks in upper Cambrian shallow water oolite and ribbon carbonates; Sedimentology 39 1101-1118.

De Boer P L, Oost A P and Visser M J 1989 The diurnal inequality of the tide as parameter for recognizing tidal influences; J. Sediment. Res. 59 912-921.

Eriksson K A and Simpson E L 2004 Precambrian tidalites: Recognition and significance; In: Tempos and events in Precambrian time: Amsterdam (ed.) Eriksson P G, Elsevier Science, pp. 631-642.

Gilleaudeau G J, Sahoo S P, Kah L C, Henderson M A and Kaufman J 2018 Proterozoic carbonates of the Vindhyan Basin, India: Chemostratigraphy and diagenesis; Gondwana Res. 57 10-25.

Gopalan K, Kumar A, Kumar S and Vijayagopal B 2013 Depositional history of the upper Vindhyan succession, central India: Time constraints from $\mathrm{Pb}-\mathrm{Pb}$ isochron ages of its carbonate components; Precamb. Res. 233 108-117.

Harazim D, Callow R H and McIlroy D 2013 Microbial mats implicated in the generation of intrastratal shrinkage ('synaeresis') cracks.; Sedimentology 60 1621-1638.

Kidder D L 1990 Facies-controlled shrinkage-crack assemblages in middle Proterozoic mudstones from Montana, USA; Sedimentology 37 943-951.

Kneller B C and Branney M J 1995 Sustained high-density turbidity currents and the deposition of thick massive sands; Sedimentalogy 42 607-616.

Kohsiek L H M and Terwindt I H I 1981 Characteristics of foreset and topset bedding in megaripples related to hydrodynamic conditions on an intertidal shoal; In: Holocene marine sedimentation in the North Sea basin (eds) Nio S D, Schllttenhelm R L E and Van Weering T J C E, IAS Spec. Publ. 5 27-37.

Kolodny Y, Taraboulos A and Frieslander U 1980 Participation of fresh water in chert diagenesis: Evidence from 
oxygen isotopes and boron a-track mapping; Sedimentology 27 305-316.

Kumar S 1978a Stromatolites and environment of deposition of the Vindhyan Supergroup of Central India; J. Palaeontol. Soc. India 21-22 33-43.

Kumar S 1978b Sedimentaries of the zone of Badolisera and the Vindhyan Supergroup, Uttar Pradesh - A reappraisal of correlation; J. Palaeontol. Soc. India 21-22 96-101.

Kumar S and Sharma M 2011 Vindhyan Basin, Son Valley Area, central India; The Palaeol. Soc. of India, Field Guide, $121 \mathrm{p}$.

Magalhães A J C, Gabaglia G P, Scherer C M S, Ballico M B, Guadagnia F, Bento Freeire E, Silva Born L R and Octavian C 2015 Sequence hierarchy in a Mesoproterozoic interior sag basin: From basin fill to reservoir scale, the Tombador formation, Chapada Diamantina Basin, Brazil; Basin Res. 28 393-342.

Malone S J, Meert J G, Banerjee D M, Pandit M K, Tamrat E, Kamevon G D, Pradhan V R and Sohl L E 2008 Paleomagnetism and detrital zircon geochronology of the upper Vindhyan sequence, Son valley and Rajasthan, India: A ca. 1000 Ma closure age for the Puranabasin? Precamb. Res. 164 137-159.

Mandal A, Koner A, Sarkar S, Tawfik H A, Chakraborty N, Bhakta S and Bose P K 2016 Physico-chemical tuning of palaeogeographic shifts: Bhuj formation, Kutch, India; Mar. Pet. Geol. 78 474-492.

McCave I N 1985 Recent shelf elastic sediments; In: Sedimentology: Recent developments and applied aspects (eds) Brenchley P J and Williams B P S, Geol. Soc. of London, Spec. Publ. 18 49-65.

McMahon S, Hood A V S and McIlroy D 2017 The origin and occurrence of subaqueous sedimentary cracks; In: Earth system evolution and early life: A celebration of the work of Martin Brasier (eds) Brasier A T, Mcllroy D and McLoughlin N, Geol. Soc. London, Spec. Publ. 448 285-309.

McMenamin D S, Kumar S and Awramik S M 1983 Microbial fossils from the Kheinjua Formation, Middle Proterozoic Semri Group (lower Vindhyan) Son valley area, Central India; Precamb. Res. 21 247-271.

Mishra M, Bickford M E and Basu A 2018 U-Pb Age and chemical composition of an Ash Bed in the Chopan Porcellanite Formation, Vindhyan Supergroup, India; J. Geol. 126(5) 553-560.

Naqvi S M and Rogers J J W 1987 Precambrian geology of India; Clarendon Press; Oxford Univ. Press, New York, Oxford, 233p.

Nio S D and Yang C S 1991 Diagnostic attributes of clastic tidal deposits: A review; In: Clastic tidal sedimentology: Calgary (eds) Smith D G, Zaitlin B A, Reinson G E and Rahmani R A, Can. Soc. Pet. Geol., pp. 3-27.

Paikaray S, Banerjee S and Mukherji S 2008 Geochemistry of shales from the Paleoproterozoic to Neoproterozoic Vindhyan Supergroup: Implications on provenance tectonics and paleoweathering; J. Asian Earth Sci. 32 34-48.

Pati J K, Reimold W U, Koeberl C and Pati P 2008 The Dhala structure, Bundhelkhand craton, central India-eroded remnant of large Paleoproterozoic impact structure; Meteor. Planet. Sci. 43(8) 1383-1398.

Prasad B and Verma K K 1991 Vindhyam basin: A review; In: Sedimetary basin of India: Tectonics context (eds) Tandon
S K, Pant C C and Casshyap S M, Gyanodaya Prakashan, Nainital, India, pp. 50-62.

Pratt B R 2002 Syneresis cracks: Subaqueous shrinkage in argillaceous sediments caused by earthquake-induced dewatering; Sedim. Geol. 117(1) 1-10.

Rai V, Shukla M and Gautam R 1997 Discovery of carbonaceous megafossils (Chauria-Tawuiaassenblagge) from the Neoproterozoic Vindhyan succession (Rewa Group), Allahabad-Rewa area, India; Curr. Sci. 73 783-788.

Rao K S and Neelakantam S 1978 Stratigraphy and sedimentation of Vindhyans in parts of Son valley area, Madhya Pradesh; Rec. Geol. Surv. India 110 180-193.

Rasmussen B, Bose P K, Sarkar S, Banerjee S, Fletcher I R and Mcnaughton N J 20021.6 ga U-Pb zircon age for the Chorhat Sandstone, lower Vindhyan, India: Possible implications for early evolution of animals; Geology 30 103-106.

Ray J S, Martin M W, Veizer J and Bowring S A 2002 U-Pb zircon dating and $\mathrm{Sr}$ isotope systematic of Vindhyan Supergroup, India; Geology 30 131-134.

Ray J S, Veizer J and Davis W J 2003 C, O, Sr and Pb isotope systematic of carbonate sequences of the Vindhyan Supergroup, India: Age, diagenesis, correlations and implication for global events; Precamb. Res. 121 103-140.

Raza M, Dayal A M, Khan A, Bhardwaj V R and Rais S 2010 Geochemistry of lower Vindhyan clastic sedimentary rocks of northwestern Indian shield: Implications for composition and weathering history of Proterozoic continental crust; J. Asian Earth Sci. 39 51-61.

Rouse R 1961 Fluid mechanics for hydralic engineers; Dover, New York.

Sallstedt T, Bengtson S, Broman C, Crill P M and Canfield D E 2018 Evidence of oxygenic phototrophy in ancient phosphatic stromatolites from the Paleoproterozoic Vindhyan and Aravalli Supergroups, India; Geobiology 16 139-159.

Sarangi S, Gopalan K and Kumar S $2004 \mathrm{~Pb}-\mathrm{Pb}$ of earliest magascopic, eukaryotic alga bearing Rohtas formation, Vindhyan Supergroup, India: Implication for Precambrian atmospheric oxygen evolution; Precamb. Res. 132 107-121.

Sarkar S, Chakraborty P P and Bose P K 1996 Proterozoic lakheri limestone, central India; facies, paleogeography and physiography; Mem. Geol. Soc. India 36 5-26.

Sarkar S, Banerjee S, Chakarborty S and Bose P K 2002a Shelf storm flow dynamics: Insight from the Mesoproterozoic Rampur Shale, Central India; Sedim. Geol. 147 89-104.

Sarkar S, Chakarborty S, Banerjee S and Bose P K 2002b Facies sequence and cryptic imprint of sag tectonics in the late Proterozoic Sirbu Shale, Central Shale; IAS Spec. Publ. 33 369-381.

Sarkar S, Eriksson P G and Chakraborty S 2004 Epeiric sea formation on Neoproterozoic supercontinent break-up: A distinctive signature in coastal storm bed amalgamation; Gondwana Res. 7(2) 313-322.

Sarkar S, Banerjee S, Samanta P and Jeevankumar S 2006 Microbial mat-induced sedimentary structures in siliciclastic sediments: Examples from the $1.6 \mathrm{Ga}$ Chorhat Sandstone, Vindhyan Supergroup, MP, India; J. Earth Syst. Sci. 115 49-60.

Sarkar S, Banerjee S, Mukhopadhyay S and Bose P K 2012 Stratigraphic architecture of the Sonia Fluvial interval, India in its Precambrian context; Precamb. Res. 214-215 $210-226$. 
Sarkar S, Banerjee S, Samanta P, Chakraborty N, Chakraborty P P, Mukhopadhyay S and Singh A K 2014 Microbial mat records in siliciclastic rocks: Examples from four Indian Proterozoic basins and their modern equivalents in Gulf of Cambay; J. Asian Earth Sci. 91 362-377.

Sarkar S, Choudhuri A, Mandal S and Bose P K 2018 Flat pebbles and their edge-wise fabric in relation to 2-D microbial mat; Geol. J., https://doi.org/10.1002/gj.3312.

Sastry M V A and Moitra A K 1984 Vindhyan stratigraphy: A review; Geol. Surv. India Memoir 116 109-148.

Schieber J 1986 The possible role of benthic microbial mats during the formation of carbonaceous shales in shallow MidProterozoic basins; Sedimentology 33 521-536.

Schieber J, Sur S and Banerjee S 2007 Benthic microbial mats in black shale units from Vindhyan supergroup, Middle Proterozoic of India: The challenges of recognizing the genuine article; In: Atlas of microbial mats features preserved within the clastic rock record (eds) Schieber J,
Bose P K, Eriksson P G, Banerjee S, Sarkar S, Altermann W and Catunneau O, Elsevier, pp. 189-197.

Seilacher A, Bose P K and Pflüger F 1998 Triploblastic animals more than 1 billion years ago: Trace fossil evidence from India; Science $\mathbf{2 8 2}$ 80-82.

Singh L B 1973 Depositional environment of the Vindhyan sediments in the Son valley area; In: Recent Researches in Geology Hindu. Pub. Corp., New Delhi, pp. 146-152.

Srivastava A P and Rajagopalan G 1988 F-T ages of Vindhyan glauconitic sandstone beds exposed around Rawatbhata area, Rajasthan; J. Geol. Soc. India 32 527-529.

Tripathy G S and Singh S K 2015 Re-Os depositional age for black shale from the Kaimur Group, upper Vindhyan, India; Chem. Geol. 413 63-72.

Valdiya K S 2010 The Making of India Geodynamics Evolution; pp. 191-193.

Visser M J 1980 Neap-spring cycles reflected in Holocene subtidal large-scale bedform deposits: A preliminary note; Geology 8 543-546.

Corresponding editor: N V ChalaPathi RaO 